\title{
Effects of concurrent low temperature and low nitrogen supply on polar and temperate seaweeds
}

\author{
Rebecca E. Korb ${ }^{1, *}$, Valrie A. Gerard ${ }^{2}$ \\ ${ }^{1}$ Wrigley Institute of Environmental Studies, University of Southern California, PO Box 5069, Avalon, California \\ 90704-5069, USA
}

${ }^{2}$ Marine Sciences Research Centre, State University of New York, Stony Brook, New York 11794-5000, USA

\begin{abstract}
Antarctic and arctic marine waters have similar near-freezing temperatures, but differ greatly in dissolved inorganic nitrogen (DIN) availability. Antarctic algae have high DIN supply yearround; arctic algae are $\mathrm{N}$-limited during the summer. Temperate algae experience low temperatures and low DIN supply on a seasonal basis, but never concurrently. Nitrogen supply influences the ability of algae to achieve the high enzyme activities necessary for cold acclimation. The present study compared $\mathrm{N}$-allocation strategies of antarctic, arctic, and temperate seaweeds grown under $\mathrm{N}$-replete and $\mathrm{N}$-limited conditions at near-freezing temperature. Sporophytes of the antarctic endemic, Himantothallus grandifolius, did not store $\mathrm{NO}_{3}{ }^{-}$, had small pools of nitrogenous compounds, and were unable to sustain growth for longer than 1 mo under $\mathrm{N}$-limitation. However, $\mathrm{N}$-starved plants with negative growth rates exhibited chlorophyll fluorescence ratios $\left(F_{\mathrm{v}} / F_{\mathrm{m}}\right)$ similar to those of $N$-replete plants, and photosynthetic rates remained positive, suggesting that PSII reaction centres (RCII) were functioning efficiently. In contrast, the arctic endemic, Laminaria solidungula, maintained relatively high growth rates during 9 mo of $\mathrm{N}$-starvation. The arctic kelp utilised both internal $\mathrm{NO}_{3}{ }^{-}$pools and organic nitrogenous components, such as protein and chlorophyll, to support growth. Despite declines in the density of RCII and photosynthetic capacity, $\mathrm{N}$-limited $L$. solidungula continued to accumulate carbon reserves. Like the arctic plants, temperate $L$. saccharina from the Atlantic coast of Maine had internal reserves of $\mathrm{NO}_{3}{ }^{-}$and organic compounds that provided the initial $\mathrm{N}$-source for growth under low external $\mathrm{N}$-supply. The internal $\mathrm{N}$-reserves were depleted fairly rapidly, however, and the temperate kelp showed simultaneous reductions in growth rate, photosynthetic capacity, and $F_{\mathrm{v}} / F_{\mathrm{m}}$ after only 3 mo under low $\mathrm{N}$-supply. Overall, the arctic species alone has an $\mathrm{N}$-allocation strategy for surviving long periods of concurrent low temperature and low $\mathrm{N}$-supply. The antarctic species appears to be primarily adapted to maintaining photosynthesis and growth under low light and low temperature, rather than low DIN supply. The temperate species is poorly adapted to survive prolonged periods of both low $\mathrm{N}$ and low temperature, even though ecotypes of this species extend into the Arctic.
\end{abstract}

KEY WORDS: Antarctic A Arctic - Growth - Himantothallus grandifolius - Laminaria saccharina Laminaria solidungula $\cdot$ Nitrogen · Photosynthesis - Temperature

\section{INTRODUCTION}

Polar seas are characterised by constant, near-freezing water temperatures, in the range of -2 to $2^{\circ} \mathrm{C}$. Photosynthetic carbon fixation is an enzyme-mediated process and is strongly temperature dependent, yet these waters support diverse and dense populations of seaweeds with high rates of primary productivity

•E-mail: korb@wrigley.usc.edu comparable to temperate algae (reviewed by Dunton \& Dayton 1995). In temperate algae, acclimation of photosynthesis to low temperature involves the maintenance of high concentrations of Calvin cycle enzymes (Davison 1987, Davison \& Davison 1987. Davison et al. 1991). It seems likely, therefore, that polar algae respond to low temperature in a similar manner. Ongoing studies of thermal responses in seaweeds endemic to the Arctic and Antarctic support this hypothesis (Newkirk 1997, Davison et al. unpubl. data). 
Activities of Calvin cycle enzymes in temperate algae are affected by nitrogen-availability, as well as temperature (Wheeler \& Weidner 1983, Gerard 1997). Although environmental conditions of arctic and antarctic marine waters are similar in terms of low temperature and low annual irradiance, they differ greatly in terms of nutrient concentrations. Levels of dissolved inorganic nitrogen (DIN) are always high in the Antarctic (Drew \& Hastings 1992), so nitrogen is probably never limiting for macroalgal growth, and photosynthetic enzyme activities are probably never limited by nitrogen supply. In contrast, DIN concentrations of arctic waters fluctuate seasonally. Ambient $\mathrm{NO}_{3}{ }^{-}$concentrations are generally highest in the winter and spring, falling to low or undetectable levels limiting to kelp growth in the summer (Chapman \& Lindley 1980, Dunton \& Schell 1986). Arctic kelps rely heavily on stored photosynthate, accumulated over the summer months, to support new tissue growth during 9 mo of ice cover (Dunton \& Schell 1986, Dunton \& Jodwalis 1988, Dunton 1990). Therefore, maximal C-fixation rates need to be achieved during the summer period of high irradiance, despite the constraints of low N-supply and near-freezing temperatures. Nutrient regimes of temperate marine waters resemble those of the Arctic, where DIN is only seasonally available (Chapman \& Craigie 1977, Gagné et al. 1982). However, temperate macroalgal communities are never subjected to concurrent low temperature and low nitrogen, as nutrient levels are generally highest in the winter, when water temperatures are lowest, and nutrient depletion coincides with increasing temperatures.

While it is well documented that kelps from seasonally low $N$ environments accumulate internal $N$-reserves that support growth when external supply is low, little information exists on strategies to survive concurrent low $\mathrm{N}$-supply and low temperature. The present study examined $\mathrm{N}$-allocation in polar and temperate seaweeds under high or low $\mathrm{N}$-supply at $0^{\circ} \mathrm{C}$. Three species were examined: the arctic endemic, Laminaria solidungula J. Ag., which experiences low N-supply and low temperature in nature; a population of Laminaria saccharina L. Lamour from the Atlantic coast of Maine, which never experiences concurrent low temperature and low DIN; and the antarctic endemic, Himantothallus grandifolius (A. \& E. S. Gepp) Moe \& Silva, which is found in a low temperature, high N environment year-round. Although, ideally, we would have used 3 species of kelp for this comparison, the order Laminariales is not found in the Southern Ocean (Moe \& Silva 1977). H. grandifolius was originally classified as a member of the Laminariales, but was reclassified in the closely related Desmarestiales (Tan \& Druehl 1996). Its morphology, physiology, and life history are similar to that of the kelps (Moe \& Silva 1981).

\section{MATERIALS AND METHODS}

Himantothallus grandifolius sporophytes, 10 to $30 \mathrm{~cm}$ in blade length, were collected from the coast of the Antarctic Peninsula near Palmer Station $\left(64^{\circ} 46^{\prime} \mathrm{S}\right.$, $64^{\circ} 04^{\prime}$ W) during March and April 1997. Laminaria saccharina sporophytes, of a similar size, were collected from the Atlantic Coast near Chamberlain, Maine, USA $\left(43^{\circ} 54^{\prime} \mathrm{N}, 69^{\circ} 28^{\prime} \mathrm{W}\right)$ in October 1997 , and sporophytes of $L$. solidungula were collected from the Canadian High Arctic at Resolute Bay, Cornwallis Island $\left(74^{\circ} 30^{\prime} \mathrm{N}, 95^{\circ} \mathrm{W}\right)$ during July 1997 . All species were collected from subtidal populations using SCUBA.

Prior to experimental treatments, plants were maintained in 81 batch cultures. A total of 14 Himantothallus grandifolius ( 3 or 4 container ${ }^{-1}$ ), 20 Laminaria saccharina (5 containe ${ }^{-1}$ ) and $24 L$. solidungula plants ( 6 container $^{-1}$ ) were held between 4 batch cultures for each species. Seawater from Long Island Sound was used at ambient salinity ( 28 to $30 \%$ ) for arctic and temperate plants, but salinity was raised to $35 \%$, by addition of $\mathrm{NaCl}$ for antarctic plants; these salinities approximated ambient conditions at the collection sites. Cultures were maintained at $0^{\circ} \mathrm{C}$ using a temperaturecontrolled incubator. Irradiance was provided by cool white fluorescent lamps at a photon flux density of 50 to $70 \mu \mathrm{mol} \mathrm{m} \mathrm{m}^{-2} \mathrm{~s}^{-1}$, on a $16 \mathrm{~h}$ light: $8 \mathrm{~h}$ dark cycle; arctic plants were grown on a $20 \mathrm{~h}$ light: $4 \mathrm{~h}$ dark cycle for the last 3 mo of the experimental treatment to maximise growth. These light intensities were saturating for growth (Fortes \& Lüning 1980, Wiencke \& Fischer 1990). Water motion was provided by aeration. Seawater was changed twice weekly, and $240 \mu \mathrm{M} \mathrm{NO}_{3}$ and $16 \mu \mathrm{M}$ PO4 were added at each water change.

To examine the effects of nitrogen limitation on $\mathrm{N}$ allocation, plants were cultured as above but under either $\mathrm{N}$-replete or $\mathrm{N}$-limited conditions. Seawater was first stripped to $<1 \mu \mathrm{M} \mathrm{NO}_{3}^{-}$and $\mathrm{NH}_{4}{ }^{+}$by 3 to 4 d exposure to Ulva lactuca cultures. To produce $\mathrm{N}$-replete plants, $240 \mu \mathrm{M} \mathrm{NO}{ }^{-}$and $16 \mu \mathrm{M} \mathrm{PO} 4$ were added at each water change. This was determined to saturate $\mathrm{N}$-content of blade tissue in temperate Laminaria saccharina (Gerard 1997). To produce $\mathrm{N}$-limited plants, only $16 \mu \mathrm{M} \mathrm{PO}_{4}$ was added to the seawater. Experiments were terminated when all plants grown without $\mathrm{NO}_{3}{ }^{-}$demonstrated negative growth rates. In the case of arctic plants, however, breakdown of the incubator after Week 36 resulted in water temperatures reaching $20^{\circ} \mathrm{C}$, terminating the experiment. Unless otherwise specified, the terms $\mathrm{N}$-replete and $\mathrm{N}$-limited refer to plants grown with or without $\mathrm{NO}_{3}{ }^{-}$ and sampled during the last week of the experiment.

Photosynthetic parameters, tissue composition, growth rates, and enzyme activities were measured at the beginning of each experiment and periodically through- 


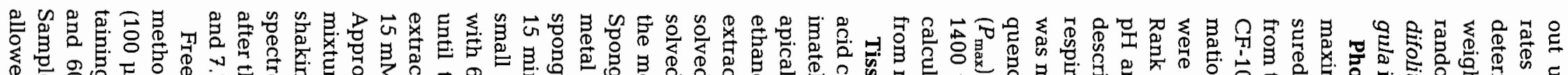

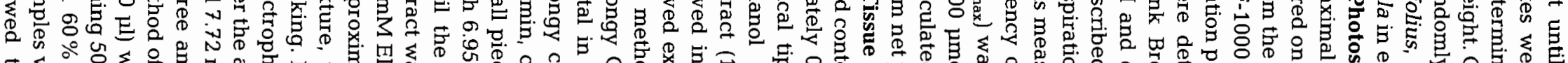

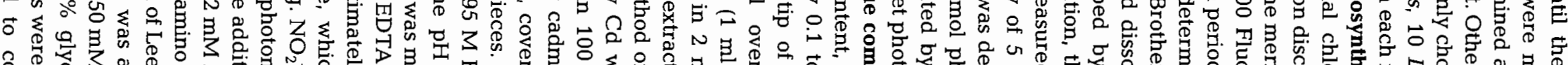

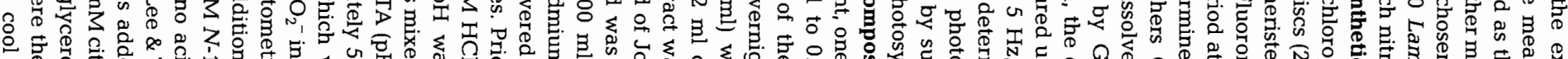

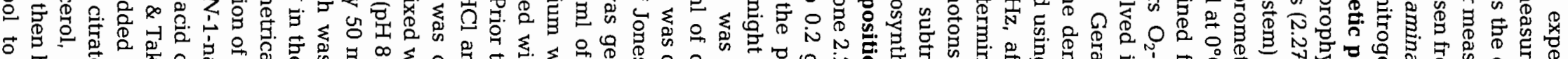

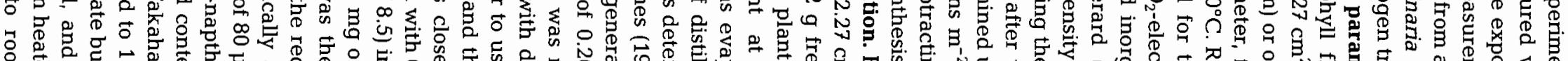

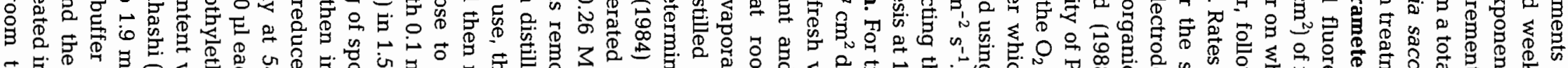

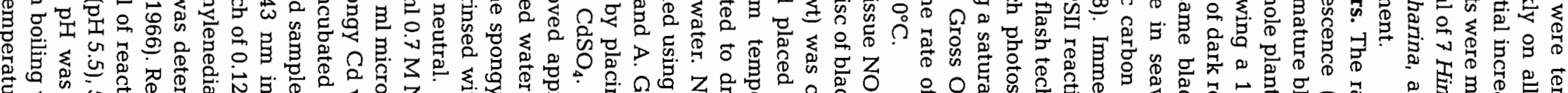

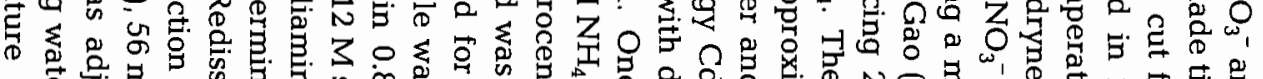

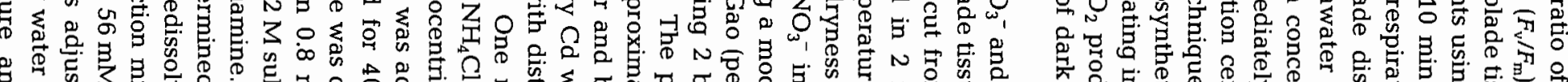

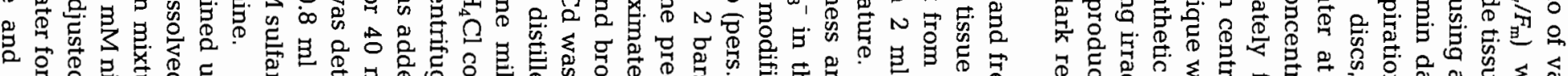

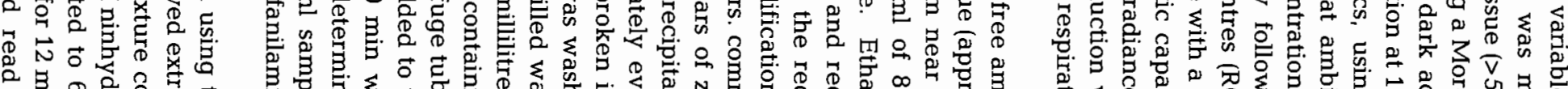

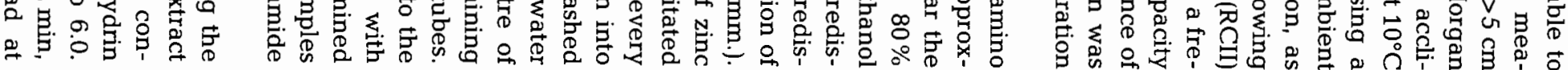

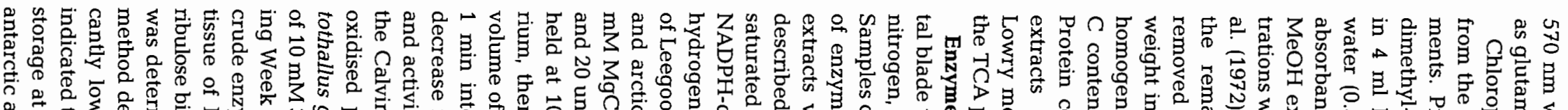

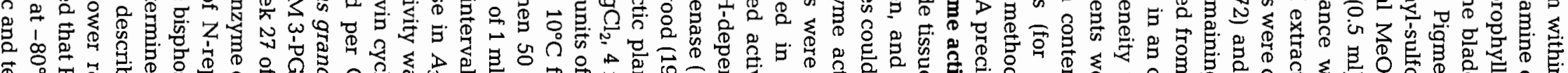

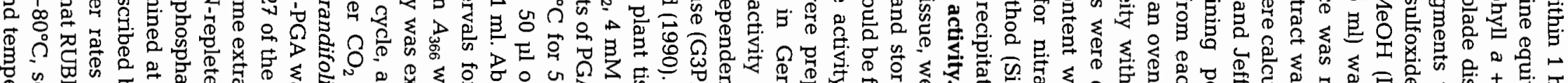

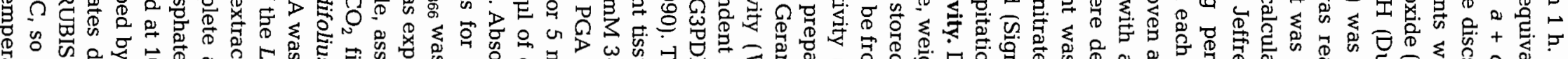

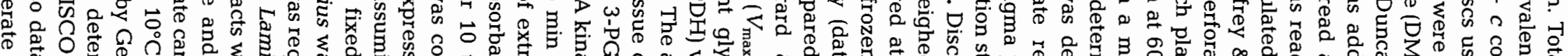

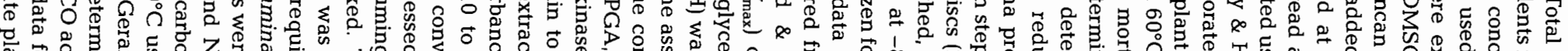

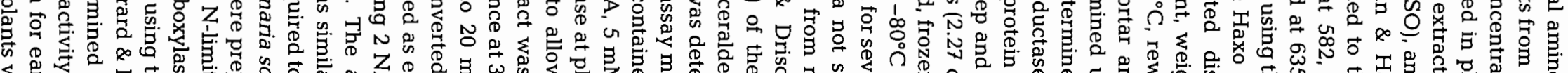

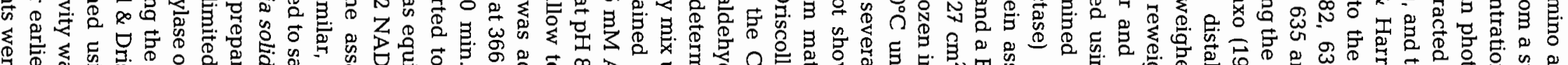

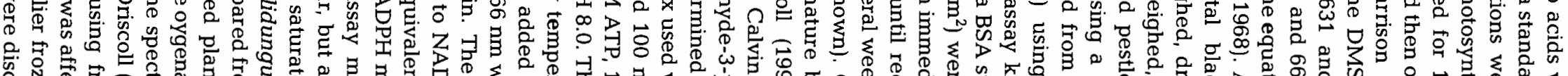

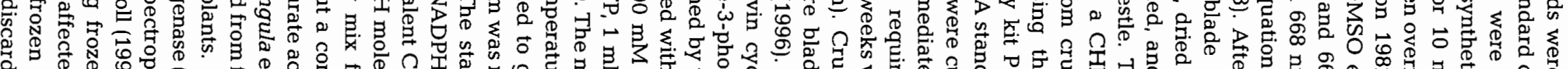

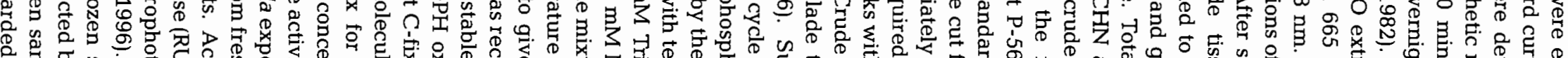

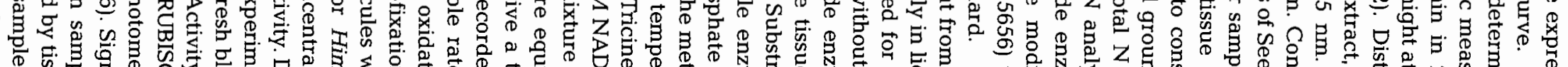

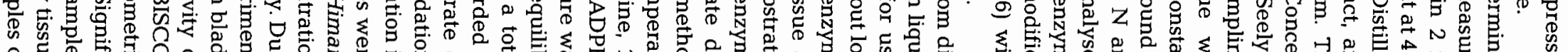

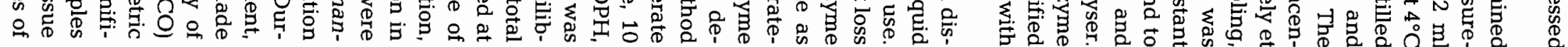


To determine nitrate reductase (NR) activity, crude enzyme extracts were prepared using a modified version of the method described by Hurd et al. (1995). Discs $\left(2.27 \mathrm{~cm}^{2}\right)$ were cut from mature blade tissue with a cork borer, frozen immediately in liquid nitrogen, and stored at $-80^{\circ} \mathrm{C}$. Frozen tissue was ground to a fine powder under liquid nitrogen with a mortar and pestle. For each $0.1 \mathrm{~g}$ wet wt of tissue (approximately $1 \mathrm{disc}), 2 \mathrm{ml}$ of ice-cold extraction buffer containing $200 \mathrm{mM}$ phosphate buffer ( $\mathrm{pH} 7.9), 5 \mathrm{mM}$ EDTA, $20 \mathrm{mM}$ dithiothreitol (DTT), $7.5 \mu \mathrm{M}$ PVP, and $1 \%$ (v/v) Triton X-100 was added. The sample was reground to homogeneity and centrifuged for $5 \mathrm{~min}$ at $4^{\circ} \mathrm{C}(10000 \times g)$. Extracts were kept on ice and assayed within $30 \mathrm{~min}$.

NR activity in the supernatant of the crude extracts was determined in an assay mixture containing $0.2 \mathrm{mM} \mathrm{NADH}, 10 \mathrm{mM} \mathrm{KNO}_{3}$ and $200 \mathrm{mM}$ phosphate buffer ( $\mathrm{pH}$ 7.9). Reactions were started by adding $0.4 \mathrm{ml}$ crude enzyme extract to $1.6 \mathrm{ml}$ assay mix. One millilitre was removed immediately and added to $1 \mathrm{ml}$ of $550 \mathrm{mM}$ zinc acetate. The remaining $1 \mathrm{ml}$ was incubated for $30 \mathrm{~min}$ at $10^{\circ} \mathrm{C}$, and the reaction was stopped by the addition of $1 \mathrm{ml}$ zinc acetate. Samples were centrifuged for $5 \mathrm{~min}(10000 \times \mathrm{g})$. Of the resulting supernatant, $0.5 \mathrm{ml}$ was removed, added to $20 \mu \mathrm{l}$ of $825 \mu \mathrm{M}$ phenazine methosulphate, and allowed to stand for $20 \mathrm{~min}$. $\mathrm{NO}_{2}{ }^{-}$was measured spectrophotometrically at $540 \mathrm{~nm}$ (Parsons et al. 1984) after the addition of $0.5 \mathrm{ml}$ each of $58 \mathrm{mM}$ sulfanilamide (in $1 \mathrm{M} \mathrm{HCl}$ ) and $3.86 \mathrm{mM} \mathrm{N}$-1-napthylethylenediamine.

Statistical analyses. Statistical analyses were made using 2-way ANOVA (Fully Factorial MGLH, SYSTAT), followed by multiple comparisons using the TukeyKramer HSD-test. Data for initial measurements (Week 0 ) were compared to measurements for $N$-limited and $\mathrm{N}$-replete plants from the final week of sampling. Statistical significance was determined as $\mathrm{p}<0.05$.

\section{RESULTS}

\section{Effects of N-limitation on growth}

Arctic Laminaria solidungula, antarctic Himantothallus grandifolius, and temperate Laminaria saccharina showed different growth responses to $\mathrm{N}$-limitation at $0^{\circ} \mathrm{C}$. Under saturating $\mathrm{N}$-supply, all 3 species grew slowly at $0^{\circ} \mathrm{C}$, averaging $0.45,0.53$ and $0.41 \% \mathrm{~d}^{-1}$ for arctic, temperate and antarctic plants, respectively (Fig. 1). Under $\mathrm{N}$-limitation, the 3 algae exhibited markedly different growth responses, and there was a significant interactive effect of algal species and $\mathrm{N}$-treatment on growth rates during the final week of each experiment (Table 1). Arctic plants survived the longest in the absence of an external $\mathrm{N}$-supply. Although growth rates were consistently lower for $\mathrm{N}$-limited plants than for $\mathrm{N}$-replete plants after the first 2 mo of the experiment, growth of $\mathrm{N}$-limited plants never became negative and was similar to growth of $\mathrm{N}$-replete plants during the final weeks. Antarctic and temperate plants were more susceptible to $\mathrm{N}$-starvation; growth rates were negative after 4 and $10 \mathrm{wk}$, respectively. Overall, arctic plants were able to maintain positive growth rates under $\mathrm{N}$-limited conditions 3 times longer than temperate plants and 9 times longer than antarctic plants.

\section{Effects of $\mathbf{N}$-limitation on tissue composition and $\mathbf{N}$-pools}

There was a significant interactive effect of $\mathrm{N}$-treatment and species (Table 1). Total $\mathrm{N}$-content of arctic and temperate plants was approximately $3 \%$ dry wt at the start of the experiment, compared to $2 \%$ in antarctic plants (Fig. 2). Under saturating N-supply, N-content of arctic and antarctic plants remained fairly constant, while $\mathrm{N}$-content of temperate plants increased. Under low $\mathrm{N}$-supply, $\mathrm{N}$-content of arctic plants gradually declined to about $1 \%$ dry wt, corresponding with

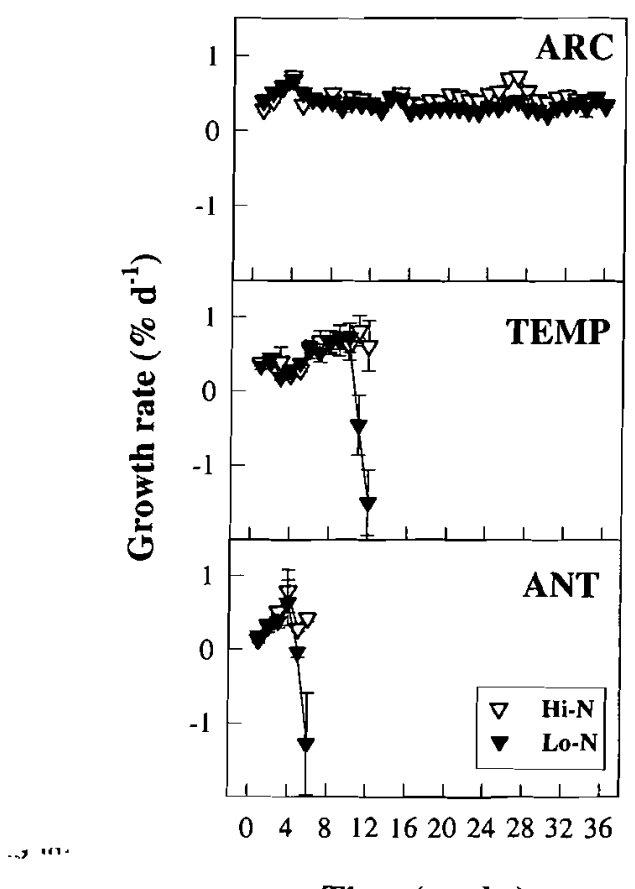

Time (weeks)

Fig. 1. Growth of arctic Laminaria solidungula (ARC), temperate Laminaria saccharina (TEMP), and antarctic Himantothallus grandifolius (ANT) at $0^{\circ} \mathrm{C}$ under $\mathrm{N}$-replete (open symbols) or $\mathrm{N}$-limiting conditions (filled symbols). Each point is a mean $\pm 1 \mathrm{SE}$ ( $\mathrm{n}=10$ to 12 plants) 
Table 1. Statistical significance of differences in effects of $\mathrm{N}$-supply on growth, tissue composition and physiological parameters of arctic Laminaria solidungula, temperate Laminaria saccharina, and antarctic Himantothallus grandifolius grown at $0^{\circ} \mathrm{C}$. Values are $F$-ratios determined using 2-way ANOVA; "significance at $\mathrm{p}<0.05$ (RCII, reaction centre $\mathrm{II}_{i}$ NR, nitrate reductase; G3PDH, glyceraldehyde-3-phosphate dehydrogenase)

\begin{tabular}{|c|c|c|c|}
\hline Parameter & N-treatment & Species & $\begin{array}{c}\text { Interactive } \\
\text { effect }\end{array}$ \\
\hline Growth & $20.1^{\bullet}$ & $3.6^{*}$ & $5.7^{*}$ \\
\hline $\mathrm{N}$-content & $488.6^{\circ}$ & $121.8^{\circ}$ & $78.5^{*}$ \\
\hline C-content & 3.5 & $189.1^{\bullet}$ & 1.0 \\
\hline Amino acids & $68.1^{*}$ & $41.4^{\circ}$ & $22.0^{*}$ \\
\hline Protein & $35.2^{*}$ & $11.9^{\circ}$ & $7.53^{\circ}$ \\
\hline Chl $a+c$ & $70.6^{*}$ & $11.7^{\circ}$ & $7.3^{*}$ \\
\hline RCll density & $114.6^{*}$ & $4.1^{\circ}$ & 3.1 \\
\hline Chl a:RCII & 0.3 & 1.6 & 0.7 \\
\hline NR activity & $10.0^{*}$ & $8.1^{*}$ & 0.8 \\
\hline G3PDH activity & $76.0^{\circ}$ & $15.9^{\circ}$ & $7.9^{\circ}$ \\
\hline$P_{\max }$ & $275.6^{\circ}$ & $5.1^{*}$ & $22.5^{\circ}$ \\
\hline$F_{\mathrm{v}} / F_{\mathrm{m}}$ & $9.9^{*}$ & $10.63^{*}$ & $10.5^{\circ}$ \\
\hline
\end{tabular}

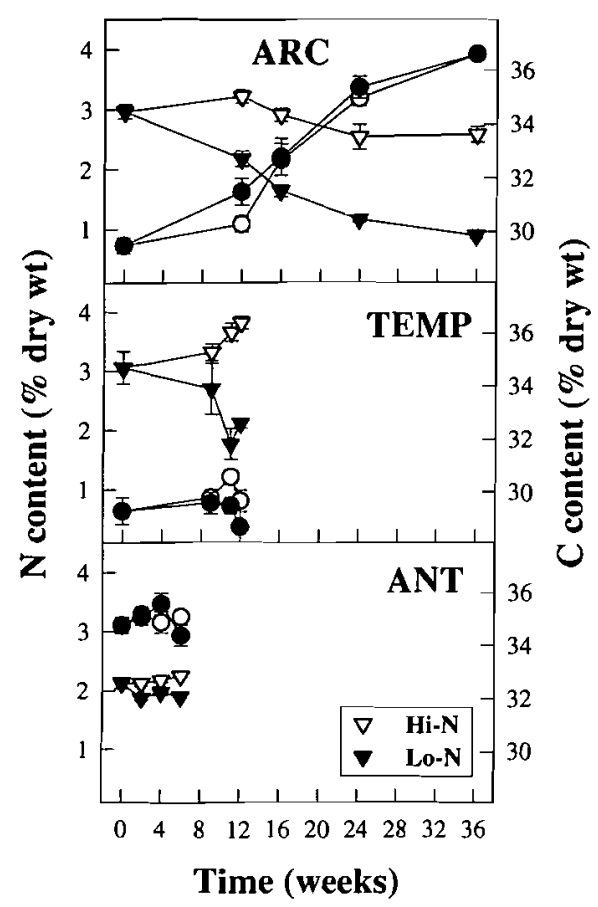

Fig. 2. N-content (triangles) and C-content (circles) for Laminaria solidungula (ARC), Laminaria saccharina (TEMP), and Himantothallus grandifolius (ANT) grown at $0^{\circ} \mathrm{C}$ under $\mathrm{N}$-replete (open symbols) or $\mathrm{N}$-limiting conditions (filled symbols). Each point is a mean $\pm 1 \mathrm{SE}$ ( $\mathrm{n}=4$ to 6 plants)

the reduction in growth rate. In contrast, $\mathrm{N}$-contents of antarctic plants were much higher $(1.9 \%)$ when they showed a drastic decline in growth. $\mathrm{N}$-content of tem-

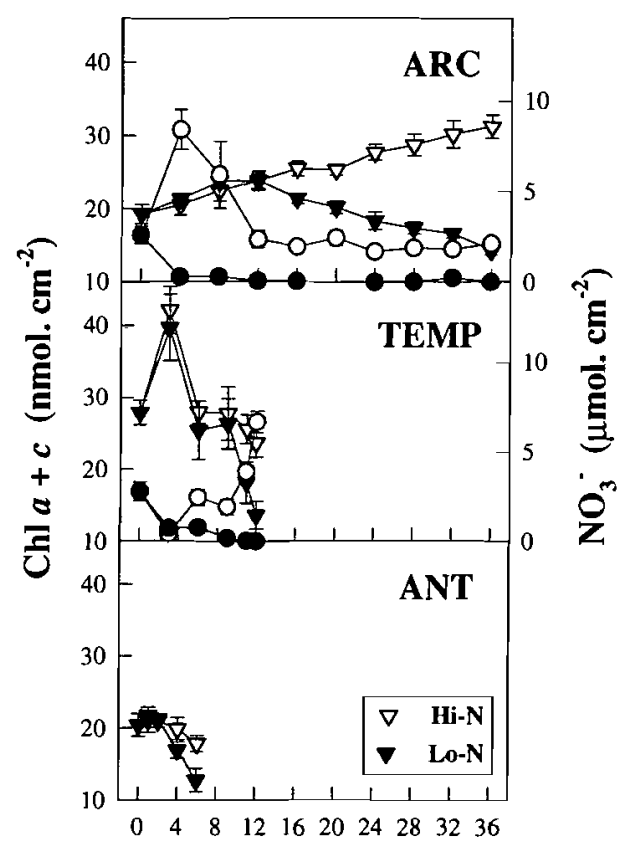

Time (weeks)

Fig. 3. Chlorophyll $a+c$ (triangles) and internal $\mathrm{NO}_{3}^{-}$(circles) for Laminaria solidungula (ARC), Laminaria saccharina (TEMP), and Himantothallus grandifolius (ANT, chlorophyll only) grown at $0^{\circ} \mathrm{C}$ under $\mathrm{N}$-replete (open symbols) or $\mathrm{N}$-limiting conditions (filled symbols). Each point is a mean $\pm 1 \mathrm{SE}$ ( $n=5$ or 6 plants)

perate plants declined to about $2 \%$ at the time that growth became negative. Growth under limiting Nsupply did not have a significant effect on C-content, which was similar for $\mathrm{N}$-replete and $\mathrm{N}$-limited plants of all 3 species (Fig. 2). However, while C-content showed little change over time in antarctic and temperate plants, C-content of arctic plants increased during both experimental treatments, indicating accumulation of reserve carbohydrates.

Tissue $\mathrm{NO}_{3}-$ provided the major source of nitrogen to support growth of arctic and temperate plants during the first 11 to $12 \mathrm{wk}$ under low external $\mathrm{N}$-supply, after which internal $\mathrm{NO}_{3}^{-}$concentrations fell to undetectable levels (Fig. 3). After internal $\mathrm{NO}_{3}{ }^{-}$pools were depleted; arctic plants grown without $\mathrm{N}$ showed low tissue concentrations of chl $a+c$, soluble protein, and free amino acids in comparison to $\mathrm{N}$-replete plants, in which nitrogenous pools increased over initial values (Figs. 3 \& 4). Antarctic plants, in contrast, had no measurable internal reserves of $\mathrm{NO}_{3}{ }^{-}$, even under saturating $\mathrm{N}$-supply, $\mathrm{N}$-limited plants showed relatively small declines in organic nitrogenous constituents compared to $\mathrm{N}$-replete plants. Temperate plants exhibited intermediate responses in organic $\mathrm{N}$-reserves. $\mathrm{N}$-starved plants had lower concentrations of chlorophyll, soluble 


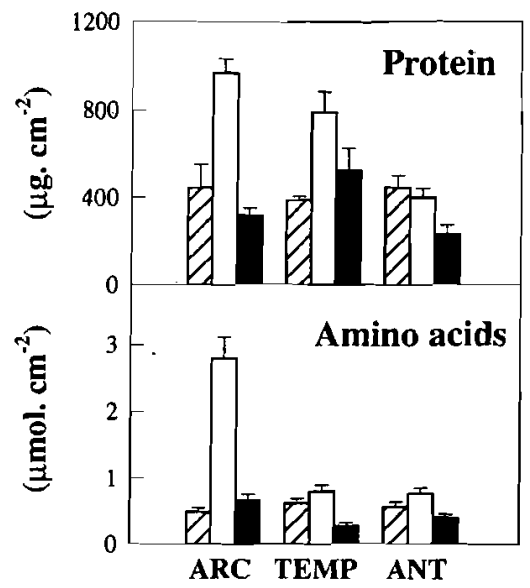

Fig. 4. Soluble protein and free amino acid pools of Laminaria solidungula (ARC), Laminaria saccharina (TEMP), and Himantothallus grandifolius (ANT) grown at $0^{\circ} \mathrm{C}$. Hatched bars represent initial (Week 0) values, open bars represent $N$ replete plants, and filled bars represent $\mathrm{N}$-limited plants during the final week of each experiment. Each bar is a mean $\pm 1 \mathrm{SE}(\mathrm{n}=5$ or 6 plants)

protein, and free amino acids than $\mathrm{N}$-replete plants, but the difference between high and low $\mathrm{N}$ treatments was generally smaller than for arctic plants, and greater than antarctic plants.

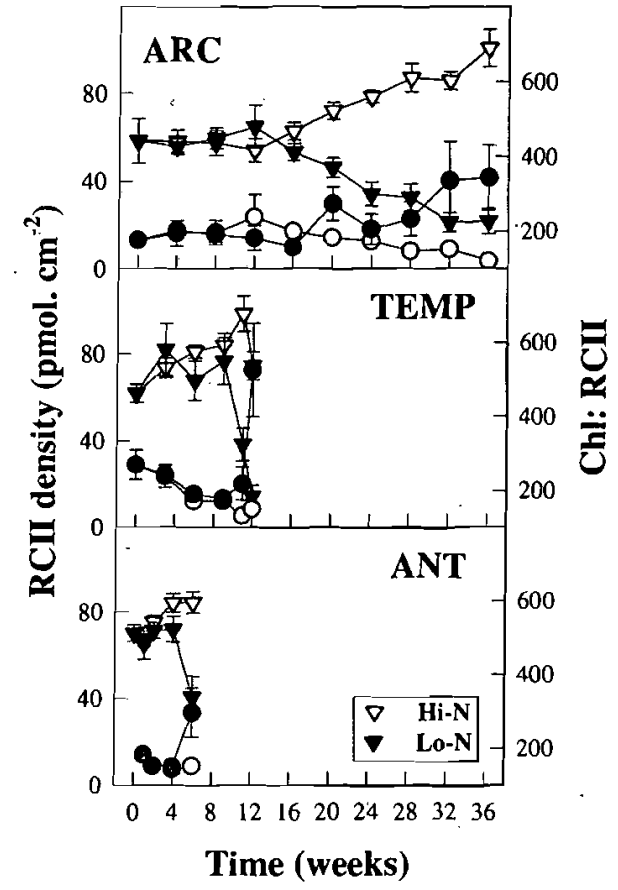

Fig. 5. RCII density (triangles) and chl a:RCII ratio (circles) for Laminaria solidungula (ARC), Laminaria saccharina (TEMP), and Himantothallus grandifolius (ANT) grown at $0^{\circ} \mathrm{C}$ under $\mathrm{N}$-replete (open symbols) or $\mathrm{N}$-limiting conditions (filled symbols). Each point is a mean $\pm 1 \mathrm{SE}$ ( $\mathrm{n}=6$ plants)

\section{Effects of $\mathrm{N}$-limitation on photosynthetic units and enzyme activity}

$\mathrm{N}$-limitation at near-freezing temperature caused significant changes in RCII density; however, the effects were similar for arctic, antarctic, and temperate plants (Table 1). All 3 species showed low RCII densities in $\mathrm{N}$-starved plants compared to $\mathrm{N}$-replete plants (Fig. 5). Conversely, chl a:RCII ultimately increased in $\mathrm{N}$-starved plants, apparently due to loss of functional reaction centres, since chlorophyll levels did not increase during the experiment (Fig. 3).

Activity of the Calvin cycle enzyme, G3PDH, declined in all 3 species grown under low $\mathrm{N}$-supply (Fig. 6). The difference between G3PDH activity of $\mathrm{N}$-replete and $\mathrm{N}$-starved plants differed in magnitude among the species, resulting in a significant interactive effect of $\mathrm{N}$-treatment and species (Table 1). $\mathrm{N}$-limitation caused the greatest difference in activity in arctic plants and the smallest difference in antarctic plants. RUBISCO activity in arctic plants also showed significantly lower rates in $\mathrm{N}$-limited compared to $\mathrm{N}$-replete plants $\left(0.6 \pm 0.1\right.$ and $1.6 \pm 0.2 \mu \mathrm{mol} \mathrm{C} \mathrm{cm}{ }^{-2} \mathrm{~h}^{-1}$, respectively, $\mathrm{n}=6$ for each treatment). As seen for G3PDH, NR activity was lower for all 3 species grown under low $\mathrm{N}$-supply compared to high $\mathrm{N}$-supply (Fig. 6).

\section{Effects of N-limitation on photosynthesis}

$\mathrm{N}$-limitation at $0^{\circ} \mathrm{C}$ had a significant effect on photosynthetic characteristics of all plants, but the response

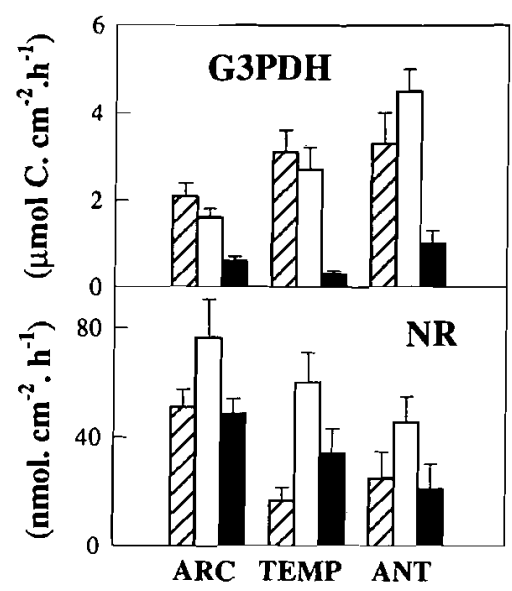

Fig. 6. G3PDH and NR activity for Laminaria solidungula (ARC), Laminaria saccharina (TEMP), and Himantothallus grandifolius (ANT) grown at $0^{\circ} \mathrm{C}$. Hatched bars represent initial (Week 0) values, open bars represent $\mathrm{N}$-replete plants, and filled bars represent $\mathrm{N}$-limited plants during the final week of each experiment. Each bar is a mean $\pm 1 \mathrm{SE}$ ( $\mathrm{n}=5$ or 6 plants) 
varied among polar and temperate species. In all 3 species, $P_{\max }$ increased over time under high $\mathrm{N}$-supply and decreased under low N-supply (Fig. 7); however, the changes occurred almost immediately in antarctic and temperate plants, and only after $12 \mathrm{wk}$ in arctic plants. The magnitude of the effect also differed among species: $\mathrm{N}$-limited antarctic plants maintained relatively high $P_{\max }$ until they died, while $\mathrm{N}$-limited arctic plants continued to grow despite significantly reduced photosynthetic capacity. The photochemical efficiency of PSII, indicated by $F_{\mathrm{v}} / F_{\mathrm{m}}$, was not affected by $N$-starvation in antarctic plants and was only slightly reduced in arctic plants, but was strongly reduced in temperate plants (Fig. 7). Thus, both $P_{\max }$ and $F_{\mathrm{v}} / F_{\mathrm{m}}$ showed significant interactive effects of $\mathrm{N}$ treatment and species (Table 1). In contrast, dark respiration was similar for $\mathrm{N}$-replete and $\mathrm{N}$-starved plants of all 3 species, and was relatively constant over the duration of each experiment (data not shown).

\section{DISCUSSION}

In the present study, arctic Laminaria solidungula, antarctic Himantothallus grandifolius, and temperate Laminaria saccharina had similar low growth rates at

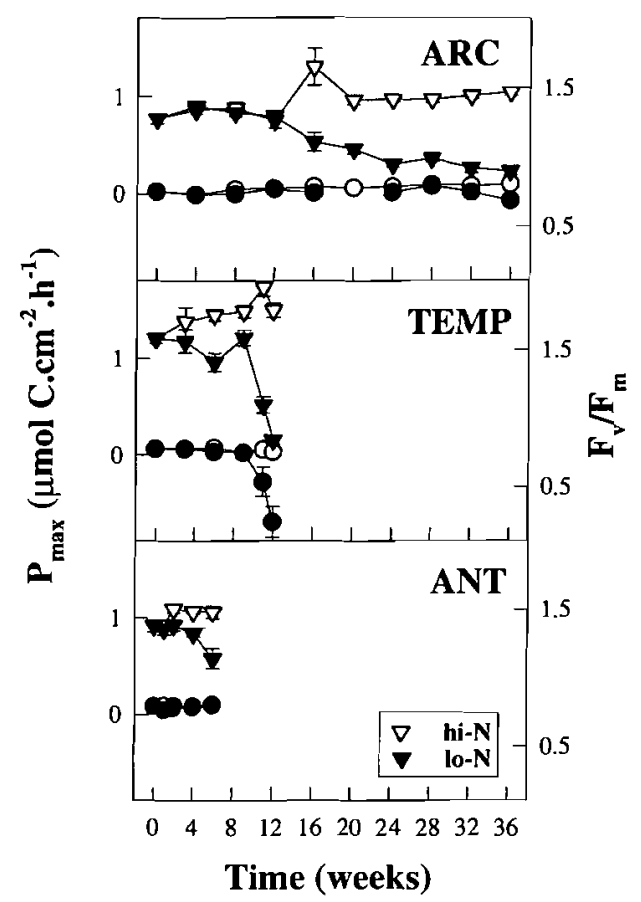

Fig. 7. Photosynthetic capacity $\left(P_{\max }\right.$, triangles) and $F_{\mathrm{v}} / F_{\mathrm{m}}$ (circles) of Laminaria solidungula (ARC), Laminaria saccharina (TEMP), and Himantothallus grandifolius (ANT) grown at $0^{\circ} \mathrm{C}$ under $\mathrm{N}$-replete (open symbols) or $\mathrm{N}$-limiting conditions (filled symbols). Each point is a mean $\pm 1 \mathrm{SE}$ ( $n=5$ or 6 plants) $0^{\circ} \mathrm{C}$, with maximum rates of $\mathrm{N}$-replete plants never exceeding $0.8 \% \mathrm{~d}^{-1}$ despite high daily irradiance. These rates were well below growth rates previously determined for $L$. saccharina at higher temperatures (e.g. Fortes \& Lüning 1980, Bolton \& Lüning 1982, Davison \& Davison 1987, Gerard 1988), indicating that growth of the temperate kelp was limited by low temperature. The low growth rates of the arctic and antarctic species, however, were similar to maximum rates determined for these polar species under a variety of culture conditions, including higher temperatures (Henley \& Dunton 1997, Newkirk 1997, Davison et al. unpubl. data for $H$. grandifolius), and high latitude seaweeds have generally been shown to achieve their highest growth rates at temperatures around $0^{\circ} \mathrm{C}$ (Wiencke \& tom Dieck 1989, tom Dieck 1992). Even when environmental factors may be most favourable for growth - for $L$. solidungula, during the late winter to early spring period of high DIN availability (Dunton \& Schell 1986), and for $H$. grandifolius, during the open water period of high irradiance (Drew \& Hastings 1992) - in situ growth rates of polar brown algae are slow relative to optimal rates for temperate species.

Inherently low maximum growth rates of polar algae may reflect a lifestyle adapted to low annual irradiance, to constant low temperature, or both. Efficient use of low ambient irradiance for C-fixation requires high concentrations of photosynthetic pigments (Falkowski \& Raven 1997), and maintenance of metabolic rates at near-freezing temperatures requires high concentrations of enzymes (Davison \& Davison 1987. Machalek et al. 1996), all of which contain nitrogen. Survival under these conditions, even with slow growth, must require relatively high levels of nitrogenous nutrients. Some polar species, such as Laminaria solidungula, depend on high rates of light-saturated C-fixation during the summer months to accumulate carbon reserves that support annual growth (Dunton 1990), and presumably require even higher concentrations of photosynthetic unit components and Calvin cycle enzymes to achieve a high $P_{\max }$ at low temperatures. Thus, the different responses of arctic, antarctic, and temperate species to concurrent low temperature and $\mathrm{N}$-limitation observed in the present study must be examined in relation to species-specific strategies for annual growth, as well as to site-specific differences in ambient $\mathrm{N}$-supply.

Himantothallus grandifolius in the Southern Ocean is never exposed to low levels of DIN. $\mathrm{NO}_{3}{ }^{-}$concentrations near the Antarctic Peninsula are on the order of 10 to $30 \mu \mathrm{M}$ year-round (M. Vernet pers. comm.). The antarctic species demonstrated little capacity for storing internal reserves of nitrogen; there were no internal pools of $\mathrm{NO}_{3}{ }^{-}$and little difference in $\mathrm{N}$-content and concentrations of organic $\mathrm{N}$-compounds between $\mathrm{N}$ - 
replete and N-starved plants (Figs. 2 to 4 ). A similar lack of $\mathrm{N}$-storage was found in temperate kelps from nutrient-rich waters (Anderson et al. 1981, Gagné et al. 1982, Espinoza \& Chapman 1983). The critical N-content at which growth became $\mathrm{N}$-limited was approximately $1.9 \%$ dry wt for $H$. grandifolius, only marginally smaller than the highest value for $\mathrm{N}$-replete plants $(2.2 \%)$. When the small pool of labile tissue $\mathrm{N}$ was depleted in the absence of an external $\mathrm{N}$-supply, the antarctic plants were unable to survive and grow. High $\mathrm{C}$-content of $\mathrm{N}$-limited plants, similar to that of $\mathrm{N}$-replete plants, further indicated that growth was $\mathrm{N}$ - and not C-limited.

Below the critical level, tissue $\mathrm{N}$ is unavailable for maintenance of photosynthetic components, accounting for the decrease in RCII density and G3PDH activity and, hence, photosynthetic capacity of N-limited Himantothallus grandifolius. The declining nitrogenous components of the photosynthetic apparatus were not utilised to support growth, however, as significant decreases in these compounds were only observed in plants showing disintegration of blade tissue. The dying plants maintained relatively high $F_{\mathrm{v}} / F_{\mathrm{m}}$, further demonstrating their inability to use photosynthetic components as labile $\mathrm{N}$-reserves. The apparently inflexible investment of available nitrogen in the photosynthetic apparatus probably reflects adaptation of $H$. grandifolius to a strongly light-limited environment. Although ambient DIN levels are sufficiently high year-round to support maximal rates of photosynthesis, irradiance levels experienced by this deep-dwelling plant ( 8 to more than $30 \mathrm{~m}$ ) are not, and the annual growth pattern closely follows the seasonal light cycle (Drew \& Hastings 1992). Thus, results of the present study indicate that the antarctic species is primarily adapted to maintaining photosynthesis and growth under low light and temperature, and has no strategy for surviving periods of low nitrogen supply.

In contrast to Himantothallus grandifolius, Laminaria solidungula is naturally subjected to concurrent low temperature and low $\mathrm{N}$-supply during the arctic summer. Temperatures remain fairly constant year-round, between -2 and $2^{\circ} \mathrm{C}$ (Sellman et al. 1992). Winter DIN levels are approximately 4 to $6 \mu \mathrm{M}$, while summer DIN levels fall below detectable limits (Chapman \& Lindley 1980, Dunton 1985). It is not surprising, therefore, that this species survived and grew longer under $\mathrm{N}$-limitation at $0^{\circ} \mathrm{C}$ than the antarctic species. However, under natural conditions of N-limitation, growth rates of $L$. solidungula have been shown to be greatly reduced (Chapman \& Lindley 1980, Dunton 1985). High growth rates, during $\mathrm{N}$-limitation, in our study may have been the result of a circannual pattern of growth, as found in some species of kelps by Lüning (1993). Under low external $\mathrm{N}$-supply, growth of $\mathrm{N}$-limited arctic plants was supported by declining internal pools of $\mathrm{NO}_{3}{ }^{-}$for about $3 \mathrm{mo}$, during which time concentrations of organic $\mathrm{N}$-compounds, such as chl $a+c$, soluble protein, and free amino acids, increased. This period approximates the duration of the low summer DIN concentrations in their natural environment, so that summer growth in situ may be largely maintained on inorganic N-reserves. In fact, Henley \& Dunton (1995) observed a significant decrease in tissue $\mathrm{NO}_{3}{ }^{-}$in fieldgrown plants over the summer. Although they may rarely, if ever, be subjected to longer periods of N-limitation in nature, the arctic plants exhibited the ability to survive and grow under low external $\mathrm{N}$-supply for much longer than $3 \mathrm{mo}$. Once internal $\mathrm{NO}_{3}{ }^{-}$was depleted, growth was apparently supported by labile organic N-compounds. After 36 wk under low N-supply, L. solidungula still exhibited growth rates comparable to rates of $\mathrm{N}$-replete plants, despite a mean $\mathrm{N}$-content of only $0.9 \%$ dry wt. These results are comparable to those of Henley \& Dunton (1997), who found that $L$. solidungula grew for 9 mo in the absence of an external $\mathrm{N}$-supply and had similarly low $\mathrm{N}$-content.

As internal pools of organic $\mathrm{N}$ compounds were used up by N-limited Laminaria solidungula, RCII density and activity of Calvin cycle enzymes decreased, and photosynthetic capacity declined. PSII efficiency, indicated by $F_{\mathrm{v}} / F_{\mathrm{m}}$, was only slightly affected, however, and increasing $\mathrm{C}$-content suggested that daily $\mathrm{C}$-assimilation exceeded the level needed to support growth. Thus, the arctic species is able to maintain sufficiently high rates of $\mathrm{C}$-fixation under summer conditions of concurrent low temperature and $\mathrm{N}$-limitation to accumulate the reserve carbohydrates that support winter growth (Chapman \& Lindley 1980, Dunton \& Schell 1986).

Of the 3 species examined in the present study, temperate Laminaria saccharina exhibited responses to concurrent low temperature and $\mathrm{N}$-limitation that were intermediate to the responses of arctic and antarctic plants. As seen in L. solidungula, growth of temperate plants was supported by internal $\mathrm{NO}_{3}{ }^{-}$pools during the first few months under low $\mathrm{N}$-supply, after which chlorophyll concentration declined. Temperate plants appeared to have fewer reserves of labile organic $\mathrm{N}$ compounds than arctic plants, however, and stopped growing and died after only a few weeks after the depletion of tissue $\mathrm{NO}_{3}{ }^{-}$. Growth became $\mathrm{N}$-limited when $\mathrm{N}$-content fell to $1.9 \%$ dry wt, similar to the critical Ncontent determined for Himantothallus grandifolius.

At the same time as growth ceased, Laminaria saccharina exhibited a decline in photosynthetic capacity even more severe than that seen in N-starved Himantothallus grandifolius, as well as a significant reduction in $F_{\mathrm{v}} / F_{\mathrm{m}}$ which did not occur in either polar species. Loss of photosynthetic performance occurred concurrently with sharp declines in RCII density and G3PDH 
activity. C-contents of $\mathrm{N}$-limited and $\mathrm{N}$-replete plants were not significantly different, however, suggesting that the rapid deterioration of these plants was not caused by a negative C-balance. The severity and rapidity of treatment effects on $L$. saccharina in the present study must be attributed to synergistic effects of low temperature and $\mathrm{N}$-starvation. Many populations of temperate kelps are seasonally subjected to low $\mathrm{N}$ supply and have the ability to accumulate $\mathrm{N}$-stores to survive these periods. L. saccharina from St. Margaret's Bay, Nova Scotia, were exposed to low $\mathrm{NO}_{3}{ }^{-}$concentrations for approximately 8 mo of the year (Chapman \& Craigie 1977, Anderson et al. 1981, Gagné et al. 1982, Espinoza \& Chapman 1983). When internal $\mathrm{NO}_{3}^{-}$pools were depleted, growth rates slowed, but plants did not demonstrate negative growth rates. However, $\mathrm{N}$-limitation of that population occurred when the water temperatures were 6 to $12^{\circ} \mathrm{C}$ i temperatures around $0^{\circ} \mathrm{C}$ coincided with high ambient DIN concentrations (Gagné et al. 1982). Near-freezing temperatures in temperate waters are also limited to winter periods of low ambient irradiance. In the present study, high irradiance coinciding with cold and $\mathrm{N}$-starvation may have caused photoinhibitory damage to photosynthetic reaction centres, as has been observed in higher plants (e.g. Blennow et al. 1998, Skillman \& Osmond 1998), accounting for the rapid decline in RCII density and $P_{\text {max }}$.

Overall, results of the present study indicate that the high costs of maintaining photosynthetic performance and growth under simultaneous near-freezing temperatures and $\mathrm{N}$-limitation limit survival strategies to species that experience these conditions on a regular basis. Himantothallus grandifolius from the $\mathrm{N}$-rich Southern Ocean lacks the ability to store and utilise internal N-reserves. Although populations of Laminaria saccharina extend into the Arctic (Dunton \& Dayton 1995) and must be exposed to concurrent low temperature and low $\mathrm{N}$-supply, temperate populations seem poorly adapted for survival under these conditions. Only the arctic endemic, Laminaria solidungula, survived and grew under sustained $\mathrm{N}$-limitation at $0^{\circ} \mathrm{C}$.

Acknowledgements. Many thanks to Alice Gao, Rutgers University, for advice and a copy of her unpubl. protocol on the spongy cadmium method for nitrate determination. Thanks also to Ken Dunton for collection of Laminaria solidungula, Jonas Collén for diving assistance, and Bill Grillo and Dave Laby for help in maintaining cultures. Funding was provided by the National Science Foundation (OPP 9521496).

\section{LITERATURE CITED}

Anderson MR, Cardinal A, Larochelle J (1981) An alternate growth pattern for Laminaria longicruris. J Phycol 17: 405-411

Blennow K, Lang ARG, Dunne P, Ball MC (1998) Cold- induced photoinhibition and growth of seedling snow gum (Eucalyptus pauciflora) under differing temperature and radiation regimes in fragmented leaves. Plant Cell Environ 21:407-416

Bolton JJ, Lüning K (1982) Optimal growth and maximal survival temperatures of Atlantic Laminaria species (Phaeophyta) in culture. Mar Biol 66:89-94

Chapman ARO, Craigie JS (1977) Seasonal growth in Laminaria longicruris: relations with dissolved inorganic nutrients and internal reserve of nitrogen. Mar Biol 40:197-205

Chapman ARO, Lindley JE (1980) Seasonal growth of Laminaria solidungula in the Canadian high Arctic in relation to irradiance and dissolved nutrient concentrations. Mar Biol 57:1-5

Davison IR (1987) Adaptation of photosynthesis in Laminaria saccharina (Phaeophyta) to changes in growth temperature. J Phycol 23:273-283

Davison IR, Davison JO (1987) The effect of growth temperature on enzyme activities in the brown alga Laminaria saccharina. Br Phycol J 22:77-87

Davison IR, Greene RM, Podolak EJ (1991) Temperature acclimation of respiration and photosynthesis in the brown alga Laminaria saccharina. Mar Biol 110:449-454

Drew EA, Hastings RM (1992) A year-round ecophysiological study of Himantothallus grandifolius (Desmarestiales, Phaeophyta) at Signy Island, Antarctica. Phycologia 31: 262-277

Duncan MJ, Harrison PJ (1982) Comparison of solvents for extracting chlor ophylls from marine macrophytes. Bot Mar 25:445-447

Dunton KH (1985) Growth of dark exposed Laminaria saccharina (L.) Lamour and Laminaria solidungula J. Ag. (Laminariales: Phaeophyta) in the Alaskan Beaufort Sea. J Exp Mar Biol Ecol 94:181-189

Dunton KH (1990) Growth and production in Laminaria solidungula: relation to continuous underwater light levels in the Alaskan high Arctic. Mar Biol 106:297-304

Dunton KH, Dayton PK (1995) The biology of high latitude kelp. In: Skjoldal HR, Hopkins C, Erikstad KE, Leinaas HP (eds) Ecology of fjords and coastal waters. Elsevier Science, Amsterdam, p 499-507

Dunton KH, Jodwalis CM (1988) Photosynthetic performance of Laminaria solidungula measured in situ in the Alaskan high Arctic. Mar Biol 98:277-285

Dunton KH, Schell DM (1986) Seasonal carbon budget and growth of Laminaria solidungula in the Alaskan High Arctic. Mar Ecol Prog Ser 31:57-66

Espinoza J, Chapman ARO (1983) Ecotypic differentiation of Laminaria longicruris in relation to seawater nitrate concentration. Mar Biol 74:213-218

Falkowski PG, Raven JA (1997) Aquatic photosynthesis. Blackwell Science, Oxford

Fortes MD, Lüning $K$ (1980) Growth rates of North Sea macroalgae in relation to temperature, irradiance and photoperiod. Helgol Meeresunters 34:15-29

Gagné JA, Mann KH, Chapman ARO (1982) Seasonal patterns of growth and storage in Laminaria longicruris in relation to differing patterns of availability of nitrogen in the water. Mar Biol 69:91-101

Gerard VA (1988) Ecotypic differentiation in light-related traits of the kelp Laminaria saccharina. Mar Biol 97:25-36

Gerard VA (1997) The role of nitrogen nutrition in high-temperature tolerance of the kelp, Laminaria saccharina (Chromophyta). J Phycol 33:800-810

Gerard VA, Driscoll T (1996) A spectrophotometric assay for Rubisco activity: application to the kelp and implications for radiometric assays. J Phycol 32:880-884 
Henley WJ, Dunton KH (1995) A seasonal comparison of carbon, nitrogen and pigment content in Laminaria solidungula and L. saccharina (Phaeophyta) in the Alaskan Arctic. J Phycol 31:325-331

Henley WJ, Dunton KH (1997) Effects of nitrogen supply and continuous darkness on growth and photosynthesis of the arctic kelp Laminaria solidungula. Limnol Oceanogr 42: 209-216

Hurd CL, Berges JA, Osborne J, Harrison PJ (1995) An in vitro nitrate reductase assay for marine macroalgae: optimisation and characterisation of the enzyme for Fucus gardneri (Phaeophyta). J Phycol 31:835-843

Jeffrey SW, Haxo FT (1968) Photosynthetic pigments of sym: biotic dinoflagellates (zooxanthellae) from corals and clams. Biol Bull 135:149-165

Jones MN (1984) Nitrate reduction by shaking with cadmium. Aiternative to cadmium columns. Water Res 18:643-646

Lee YP, Takahashi T (1966) An improved colorimetric determination of amino acids with the use of ninhydrin. Anal Biochem 14:71-77

Leegood RC (1990) Enzymes of the Calvin cycle. In: Lea PJ (èd) Enżymes of primary metabolism. Academic Press, London, $p$ 15-37

Lüning K (1993) Environmental and internal control of sea- sonal growth in seaweeds. Hydrobiologia 260:1-14

Machalek KM, Davison IR, Falkowski PG (1996) Thermal acclimation and photoacclimation of photosynthesis in the brown alga Laminaria saccharina. Plant Cell Environ 19: 1005-1016

Moe RL, Silva PC (1977) Antarctic marine flora - uniquely devoid of kelp. Science 196:1206-1208

Moe RL, Silva PC (1981) Morphology and taxonomy of $\mathrm{Hi}$ mantothallus (including Phaeoglossum and Phyllogigas), an Antarctic member of the Desmarestiales (Phaeophyceae). J Phycol 17:15-29

Editorial responsibility: Otto Kinne (Editor), Oldendorf/Luhe, Germany
Newkirk SG (1997) Mechanisms of cold adaptation in arctic kelps. MS thesis, State University of New York, Stony Brook

Parsons TR, Maita Y, Lalli CM (1984) A manual of chemical and biological methods for seawater analysis. Pergamon Press, Oxford

Seely R, Duncan MJ, Vidaver W (1972) Preparative and analytical extraction of pigments from brown algae with dimethyl sulfoxide. Mar Biol 12:184-188

Sellman PV, Delaney AJ, Chamberlain EJ, Dunton KH (1992) Seafloor temperature and conductivity data from Stefansson Sound, Alaska. Cold Regions Sci Tech 31: 491-543

Skillman JB, Osmond CB (1998) lnfluence of nitrogen supply and growth irradiance on photoinhibition and recovery in Heuchera americana (Saxifragaceae). Physiol Plant 103: $567-573$

Tan IH, Druehl LD (1996) A ribosomal DNA phylogeny supports the close evolutionary relationships among the Sporochnales, Desmarestiales, and Laminariales (Phaeophyceae). J Phycol 32:112-118

tom Dieck I (1992) North Pacific and North Atlantic digitate Laminaria species (Phaeophyta): hybridization experiments and temperature responses. Phycologia 31:147-163

Wheeler WN, Weidner M (1983) Effects of external inorganic nitrogen concentration on metabolism, growth and activities of key carbon and nitrogen assimilatory enzymes of Laminaria saccharina (Phaeophyceae) in culture. J Phycol 19:92-96

Wiencke C, Fischer G (1990) Growth and stable carbon isotope composition of cold-water macroalgae in relation to light and temperature. Mar Ecol Prog Ser 65:283-292

Wiencke C, tom Dieck I (1989) Temperature requirements for growth and temperature tolerance of macroalgae endemic to the Antarctic region. Mar Ecol Prog Ser 54:189-197

Submitted: June 10, 1999; Accepted: November 5, 1999 Proofs received from author(s): May 3, 2000 